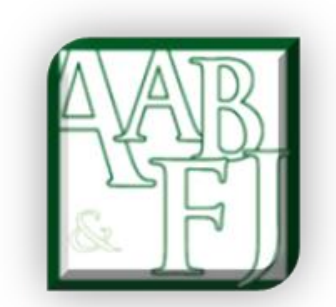

\title{
Scaling Impact Investment for Sustainable Development Goals: An Empirical Analysis
}

\author{
Seema Tewari ${ }^{1}$, Harjit Singh ${ }^{2}$, Shobhit Wadhwa ${ }^{3}$ and Deepak Tandon ${ }^{4}$
}

Abstract: Impact Investing is a community of investors willing to create social and environmental impact along with financial returns by investing either directly with Base of Pyramid ${ }^{5}$ (BoP) enterprises or indirectly through enterprises that help in creating impact by investing in BoP organizations. Adoption of SDGs ${ }^{6}$ quantified the expectation paradigm of the global community for social, environmental and economic achievable and projected/targeted achievement of SDGs by 2030 made the governments, businesses, institutions daunted with the task in hand hence, it is imperative for investing community to contribute its share as well. With high social need and underserved population India has become a test bed for impact investing. However, with increasing impact investing, Impact Measurement and Management (IMM) gains significant importance as it allows investors to evaluate impact and channelize fund to most effective solutions. The present study conducted for year 2019 not only attempts to explore impact investing landscape in India and its future dimension but it simultaneously does content analysis of impact report of investors using impact value chain ${ }^{7}$ and indicators developed on the basis of SDGs targets and indicators. The analysis aims to establish a link between developed indicators and impact, the link once established, developed indicators will provide agile, cost effective, quantifiable and measurable basis to impact that has worldwide acceptance.

Key Words: Impact Investing, Sustainable Development Goals (SDGs), Impact Measurement, Impact Metrics, Indicators.

JEL Codes: G11, P33, Q01.

\footnotetext{
${ }^{1}$ Amity University, India

${ }^{2}$ Amity University, India

${ }^{3}$ Ni-Met Metals Inc., Canada

${ }^{4}$ International Management Institute, India

${ }^{5}$ Base of Pyramid refers to the poorest two-third of the economic human pyramid living in abject poverty.

${ }^{6}$ SDGs, adopted in 2015 by all UN member states, are universally accepted goals and targets under goals to guide sustainable development and create a sustainable world for all.

${ }^{7}$ Impact Value chain is a tool build on theory of change to illustrate how enterprise activities lead to desired outcome and impact by setting a relationship between activities, output, outcome and impact.
} 


\section{Introduction}

Words penned after successful completion of Social Impact Bond 2010 by Ex- Prime Minister of United Kingdom Gordon Brown narrates the birth and rise of Impact Investment. Impact investment defined as "investments made with the intention to generate positive, measurable social and environmental impact alongside financial return" (Global Impact Investing Network (GIIN), demonstrates that Impact investors follow the philosophy of "doing good while doing well" and doesn't entirely forgo the concept of financial return, like philanthropic fund, while striving for social and environmental impact. Impact investors fall in-between the continuum of philanthropic investors and traditional investors (IRIS \& Global Impact Investing Network, 2019). It is different from Socially Responsible Investing ${ }^{8}$ (SRI) as it follows positive investing rather than screening out negative investing and also from Economic, social and governance (ESG) investing in a sense that at the core of its philosophy is intentionality of achieving "measurable" impact in conjunction with financial return. Though "measurability" of impact is the sole differentiator, the questions "what, why, how and how much" emanate different responses across impact investing community. Efforts for standardization of impact industry sprouted the idea of formation of GIIN by The Rockefeller Foundation "to support maturation and professionalization of impact investing" (Reisman et al., 2018). The efforts shaped interesting metrics by players of industry like Omidyar Network, Acumen, Mac Arthur Foundation and GIIN but standardization failed to grab the attention of practitioners as "standardisation does not allow for the customization and contextualization necessary to capture real change in people's lives" (Reisman et al., 2018).

Despite all these problems, proliferation of impact investing has not been impeded; Investors contextualize the impact based on prevalent condition in operating regions and market and strive to develop their own context oriented metrics. Investors kept themselves focused on a promising but unproven ideas and thereby support innovation financially and technologically to sustain its growth through performance and risk absorption (Shamika et al., 2019) This philosophy resonates in the preferred option of providing seed funding to investees, which provide support to such unproven ideas by impact investors, they not only provide patient capital but also guide investee at every stage until investee developed the scalability and investability to the level where traditional investors consider them an ideal case for investment. Adoption of SDGs in 2015 by all United Nations member states quantified the horizon for expectations of global community for social, environmental and economic achievable. SDGs are systematically and scientifically defined set of goals and targets. The "goals and targets can be seen as a network, in which link among goals exist through targets that explicitly refers to multiple goals" (Le Blanc, 2015). Now that published impact reports of investors reflects the idea of impact investment contribution to SDGs, a conversion of SDGs targets and indicators (developed by Inter-Agency and Expert Group on Sustainable Development Goals) into impact measurement indicators for impact investors/investees will set up a more credible basis to impact investing (Schonewille, 2018) as it will help to elucidate impact into tangible results.

\footnotetext{
${ }^{8}$ Socially Responsible Investing is an investment in enterprise that does business in positive and responsible way.
} 


\subsection{Impact Investing in India}

In 2001, Aavishkaar initiated the first for-profit fund in India and set in motion impact investing ${ }^{9}$ journey in India. Simultaneous entry of Acumen Fund gave impetus to conceptualization and cementation of the idea of impact investing (Shamika et al., 2019). It has got enough momentum after Companies Act, $2013^{10}$ whereby companies are required to spend $2 \%$ of their net profits in corporate social responsibility once they achieved earmark threshold of profit. This mandate mobilized companies to look for collaborative avenues with organisations that can deliver far reaching results, impacting a wider populace like transportation, healthcare, education, waste management etc. India has a pool of 30 Impact investors and eco system players (as per Impact Investors Council, India) that are busy in changing the landscape of impact investing in India. With a large population having unmet needs and small budgetary support for education, healthcare, social security etc., the impact investing space in India is proliferating, in fact India is going to be a test bed for many such investment.

However, assumption of creating impact and claim of created impact backed by data is altogether a different story. This study aims to bridge this gap and tries to develop indicators for measurement of impact in agriculture, education and health taking direction from targets/indicators of SDGs and internationally developed standardised metrics where available and checks the applicability of same by investors/investees operating in this space. The study also studied the landscape of impact investing in India. In the forthcoming section we will review the literature which will be followed by Research Methodology in section 3, under Research Methodology an outline of impact value chain and indicators has been enumerated, Section 4 will be Analysis and Discussion, Section 5 is Conclusion and section 6 concludes the paper with Managerial and Societal Implications.

\section{Literature Review}

The 2005 UN world summit defines economic development, social development and environmental protection as three dimensions of sustainable development which are interdependent and mutually reinforcing, where environment is a limiting factor, supporting society and economy by yielding its finite resources (Padel et al., 2015). With increasing population and finite resources, humanity needs to rethink the systems it lives with like the transportation system, the healthcare system, the education system, the food system and the financial system. Impact investing is one such tool to change the financial system (Wendt, 2018).

Levine and Emerson (2011) suggested that impact investing gave rise to the idea of chasing financial returns and also develop prospect for solution to meet social and environmental challenges. The deep optimism of impact investors in the roles of business in advancing common good and achieving social impact and of social enterprises in employing financial tools and achieving greater good played role in advancement of impact investing. A report published by Morgan (2010) believed that the lives of poor and vulnerable can be improved greatly by impact investing. Impacts investing also aim for larger environmental benefits and the chosen investees have a capability to deliver positive impact through products and processes.

To address the double bottom line (Financial return alongside environmental and social impact), impact investors adopted the route of positive investing in social enterprise. Chua et al (2011)

\footnotetext{
${ }^{9}$ Impact investing refers to a blend of traditional commercial investing with philanthropic investment. It adds commercial investment objectives of financial return with positive, measurable social and environmental impact.

${ }^{10}$ The Companies Act, 2013 consolidates and amends the law relating to companies.
} 
outlined the criteria of social enterprise that needs to be targeted by impact investing- "satisfy an existing (unmet) market demand, have an explicit social mission or have the potential to be sustainable business and real impact". Investors are desirous of knowing the achievement of social and environmental through their investment, to this end they can use three basic parameters of impact- "enterprise impact ( social value of goods, services or other benefits provided by investee enterprise), investment impact (investor's financial contribution to the social value created by investee) and nonmonetary impact (various contribution besides dollar that investors, fund managers and others may make to enterprise social value" (Brest and Born, 2013).

O'Flynn and Barnett (2012) have suggested five criteria for more evaluative approach- impact (effect on society and environment), differential impact (who benefits and who doesn't), plausible causality (difference made, if yes, how), aggregation of impact (at an investment or portfolio level) and accountability (do employees and citizens have a voice). Reeder and Colantonio (2013) while emphasizing the difficulty in measuring social and environmental return raised a valid point they quoted that "there is no (valid) methodology to measure Social and Environmental Return"11 (SER) that can be instigated by simply processing a button and waiting for a result to appear. The application of techniques requires human assessors with human mind-sets, working in human context".

To arrest the impact along entire value chain, Hehenberger et al (2013) developed a value chain known as "impact value chain" demonstrated as below: -

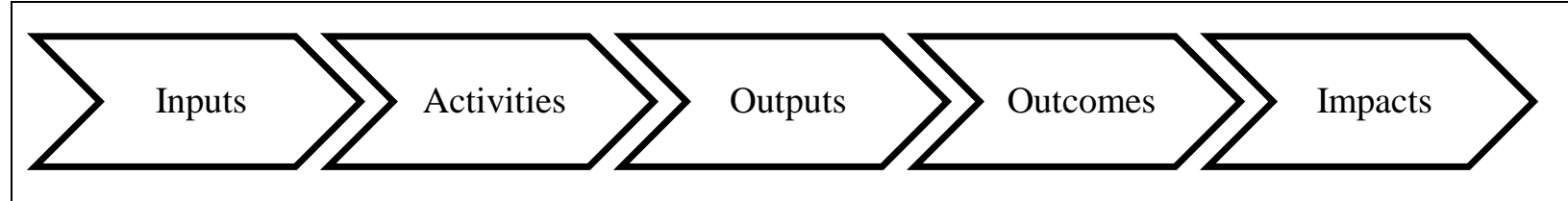

\begin{tabular}{|l|l|l|l|l|}
\hline Resources & $\begin{array}{l}\text { Concrete } \\
\text { Actions }\end{array}$ & $\begin{array}{l}\text { Tangible products } \\
\text { \& services from } \\
\text { activities }\end{array}$ & $\begin{array}{l}\text { Change resulting } \\
\text { from output }\end{array}$ & $\begin{array}{l}\text { The combination of activities, } \\
\text { outputs and outcomes adjusted } \\
\text { from what would happen } \\
\text { anyways, actions of others \& } \\
\text { unintended consequences }\end{array}$ \\
\hline
\end{tabular}

Vorosmarty et al. (2018) emphasized on scientific measurement and requirement to draw knowledge from other fields as well to measure impact. They suggested establishing a causal link chain in output, outcomes and impact and developing a context based metrics. They advocated an approach to combine outputs with outcomes and impacts. Jackson (2012) stated "current practice in evaluation of impact investing still tends to focus on counting inputs and outputs and telling stories. Most of the actors involved in the impact investing industry understand that the process of achieving meaningful social impact in poor countries is complex, nuanced, dynamic and impact, often uncertain". Highlighting the need for bringing investors and evaluators together Reisman et al. (2018) argued that demonstration of value generated through intervention or impact

\footnotetext{
${ }^{11}$ Social and Environmental Returns(SER) are non- financial returns and linked to social and environmental benefits received by impact beneficiaries, as interpreted by impact investors. Impact and SER are conceptually different as impact is perceived by investment recipients and then distilled into SER by impact creators.
} 
investments, the social impact can be realised in addition to financial return, will require more cooperation from evaluators and investors. Since evaluation of social impact is a developed field and investors can capitalize on evaluator's knowledge.

Interesting metrics were developed to do ex-ante and ex-post analysis till now, Addy et al. (2019) developed a new metric "Impact Multiple of Money ${ }^{12}$ (IMM)" to assess ex-ante impact for investment selection by "Rise Fund". They advocate six step processes where relevance and scale, alignment of social and environmental objectives, economic value of outcome and terminal value plays an important role. They also emphasized requirement of an anchor study to validate expectations.

Lewis et al. (2016) while raising their apprehension about metric based measurement stated "metrics are mainly restricted to documenting changes to internal business practice but offer limited guidance of whether a company's actions, products and services promote human wellbeing or preserve environmental integrity in the external real world domain, feeling reluctance on the part of otherwise enthusiastic investors". Perception of impact may also vary as Epstein \& Yuthas (2014) stated that financial returns are an objective estimate that could be made by financial analyst and it remains the same regardless of investor, social return are value based and will vary from investor to investor. Each investor determines his or her own unique set of impact factors that will be used to rate the investment. Brimble et al. (2013) tried to correlate investing with religious beliefs and found importance of SRI and financial criteria is more or less similar despite of magnitude of religious beliefs.

With the adoption of SDGs, government, business and institutions are daunted with task at hand. De Silva Lokuwaduge et al. (2020) identified the changing role of business to contribute positively to sustainability, SDGs for which considered a common measure. Impact investing equally contributes to this changing scenario and without positive impact investing; achievement of SDGs seems a farfetched dream. Since impact investing is aligning itself to SDGs, Schonewille (2018) has advocated the use of SDG indicators to match the impact report released by investments firms, associated business as well as other impact measurement systems and suggested the development of new framework out of SDGs to create effective impact measurement systems for impact investors and thus legitimizing impact investing and bringing it in the forefront of SDGs.

\subsection{Research Gap}

Impact investing has gained a significant traction in past few years among investors like development financial institutions, family offices, high net worth individuals, pension funds, private offices etc., lack of nimble, cost effective and credible impact management and measurement system is driving many others away. SDGs are galvanising efforts of global community to create a sustainable world and presented its targets as key performance indicators. Schonewille's study has propagated the same idea stating that a reliable indicator framework can be developed from SDGs that will give credible basis to impact investing. Current study is an attempt to develop indicators for impact measurement based on SDGs and its target.

\footnotetext{
${ }^{12}$ Impact Multiple of Money (IMM) is a methodology developed by Rise Fund to estimate the economic value of social impact associated with a set of business outputs.
} 


\subsection{Theoretical Framework}

Impact investment is a blend of philanthropic and commercial investment philosophy. While commercial investment is guided by financial return (with adjusted risk) philanthropy concern itself with realization of social objective. Yardsticks and data are easily available to measure financial return but case is not so with social and environmental impact, hence it becomes imperative to develop yardsticks for measurement of social and environmental impact of interventions. The "theory of change" which refers to the construction of a model that specifies (usually visually) the underlying logic, assumptions, inferences, causal linkages and outcome of a development program is being used to link ingredients of "impact value chain" of Hehenberger. SDGs, globally acknowledged and desired goals, are used as social and environmental impact objectives. A contextual matrix is being developed by visualising outcome that can be achieved through designated outputs and long term outcome that leads to achievement of impact that are defined in terms of SDGs. Once outcomes and impacts are visualised indicators are developed to collect data to monitor the accomplishment of same. As per Davis et al. (2012) "An indicator is a named rank ordered data that purports to represent the past or projected performance of different units". These indicators are then used as codes for analyse impact reports of investors to show how impact investing is doing as far as achievement of SDGs is concerned.

\section{Research Methodology}

\subsection{Objectives}

Research Methodology employed to achieve twin objectives:

- To study the landscape of impact investment in India.

- To find out the applicability of developed indicators to measure impact and as a tool in establishing that impact investment contribute to achievement of SDGs.

The research conducted is a cross sectional one where primary source of data is a survey instrument and secondary source is impact report related to year 2019 of investors who participated in survey at particular point of time from Oct'2019 to Mar'2020, the study has quantitative as well as qualitative approach. Questionnaire- survey instrument has both multiple choice and open ended questions and the purpose of questionnaire is to understand trends of impact investment in India. Survey is supplemented with data from Impact Investors council (IIC) of India ${ }^{13}$ that IIC collected in co-ordination with Duke University in 2017 and Brooking Survey 2019. Secondary sources of data are employed to check the feasibility of applying developed/selected indicators to measure impact and show a positive link between impact and SDGs. Since indicators are developed based on targets/indicators of SDGs, it has been assumed that availability of data on these indicators posits a positive contribution of impact investment to SDGs.

Our survey instrument consists of three part and twenty questions- general information of investor, investment information and investee information and impact measurement having 6, 4 and 10 questions respectively. Questionnaire has been checked for reliability and validity. To check the applicability of referenced indicators, we used content analysis, it is defined as a "research technique for making replicable and valid inference from texts (or other meaningful matter) to the

\footnotetext{
${ }^{13}$ Impact Investors Council (IIC) is a national member based industry body to strengthen impact investing in India, its mission is to encourage private capital to bridge the social investment gap in India.
} 
contexts of their use" (Krippendorff, 2004). "Content analysis is unique in that it has both quantitative" (Krippendorff, 2004) "and qualitative methodology" (Berg, 2002). Here we used quantitative content analysis, "facts from the texts are represented in the form of frequency expressed as percentage of actual no of key categories" (Berelson, 1952, Krippendorff, 2004, Neuendorf, 2002).

\subsection{Sample Size}

The sample for study is drawn from a population of impact investors registered with IIC. A list of 30 members on website includes impact investors and other ecosystem players. Request for participation in survey has been sent to all impact investors but survey instrument has been sent to only those who agreed to participate in survey. So our non-probability sampling count comes out to be ten. Impact reports of annual year 2019, of these ten investors having 149 unique investees (as seven investees received funding from more than one investor) have been studied to gather data on developed indicators.

\subsection{Development of Impact Value Chain and Indicators for Content for Impact Measurement}

Impact Measurement Indicators are developed for sector-agriculture, education and healthcare, the sector selection has its basis on relative importance of and influence on creating social and environmental good. Agriculture employs approximately 50\% of Indian population impact investment in agriculture enhances the asset performance which in turn contributes positively to ecosystem. Education- a source of empowerment- creates a scientific method of enquiry, reasoning and questioning ability of people. It has been given the driving seat in SDG through target 4.7. With $28 \%$ population in India in 0-14 group and $4.6 \%$ budget allocation for education, this sector is a ripe case for impact investment. Pandemic "Covid-19" taught us a lesson that healthcare shall not be a subject of negligence. With $50 \%$ population living in poverty, increasing cost of healthcare may push them down deeper, since public expenditure is not adequate to take care of all, impact investing is making a case for itself in this sector.

To develop indicators for these sectors, we relied on Hehenberger "Impact Value Chain" to define various outcome and impact created by activities/output in these sectors. Sector represents the main sector, impact category specifies the sub sector and impact theme defines the SDGs affected by outcome and impact created in that sub-sector. Outcome and impact have been developed with the help of SDGs targets. Impact may take many dimensions, it is internalizing in organization itself (impact created by investee by employing people, improving their live, creating equitable work environment, promoting innovation etc) and externalize by impacting life of external stakeholder. Since our objective is to deduce what and how of impact investment on SDG, we concerned ourselves with indicators broadly cover external stakeholders. Indicators are a mix of self-developed, IRIS ${ }^{14}+$ and Global Indicator Framework developed by Inter Agency Expert Group on Sustainable Development Goals (SDG Indicators) and measure the outcome and impact defined in impact value chain (UN SDG 2019).

\footnotetext{
${ }^{14}$ IRIS, a system maintained by GIIN, provides a catalogue of standardized metrics that investors can use to measure the impact of investments in their portfolios.
} 
Table 1: Impact value chain and indicators for agriculture sector

\begin{tabular}{|c|c|c|c|c|c|}
\hline \multirow[t]{2}{*}{$\begin{array}{l}\text { General } \\
\text { Category }\end{array}$} & \multicolumn{3}{|c|}{$\begin{array}{c}\text { Impact Value Chain } \\
\text { (Category- outcome \& impact) }\end{array}$} & \multirow[t]{2}{*}{ Impact Theme } & \multirow[t]{2}{*}{$\begin{array}{l}\text { Indicators } \\
\text { (Codes) }\end{array}$} \\
\hline & Output & Outcome & Impact & & \\
\hline Technology & $\begin{array}{l}\text { - Sensors, Machines } \\
\text { - Information } \\
\text { Technology } \\
\text { - Agriculture Waste } \\
\text { Management }\end{array}$ & $\begin{array}{l}\text { - Increased Production } \\
\text { - Reduction in use of } \\
\text { water/fertilizer/electricity/pesti } \\
\text { cides/human activity } \\
\text { - Low pollution due to } \\
\text { agriculture waste management }\end{array}$ & $\begin{array}{l}\text { - Sufficient and sustainable } \\
\text { agriculture production } \\
\text { - Reasonable prices making it } \\
\text { affordable for all } \\
\text { - Lower pressure on national } \\
\text { resources } \\
\text { Increased Worker safety }\end{array}$ & $\begin{array}{l}\text { No Poverty, Zero } \\
\text { Hunger, Decent Work \& } \\
\text { Economic Growth, } \\
\text { Reduced Inequalities, } \\
\text { Responsible } \\
\text { Consumption \& } \\
\text { Production }\end{array}$ & $\begin{array}{l}\text { Total Indicators: } 16 \\
\text { Ex: } 1 \text {. No. of sales to } \\
\text { small farmer and area } \\
\text { cultivated by them } \\
\text { 2. Change in cultivated } \\
\text { area due to technology }\end{array}$ \\
\hline $\begin{array}{l}\text { Smallholder } \\
\text { Framer }\end{array}$ & $\begin{array}{l}\text { - Storage and } \\
\text { marketing solutions } \\
\text { - Information and credit } \\
\text { availability } \\
\text { - Seed and harvesting } \\
\text { solution }\end{array}$ & $\begin{array}{l}\text { - Better price negotiations } \\
\text { leading to income growth } \\
\text { - Better quality crop leading to } \\
\text { nutrition } \\
\text { - Less waste due to better } \\
\text { storage and longer shelf life } \\
\text { - Income growth as there is no } \\
\text { lost opportunity }\end{array}$ & $\begin{array}{l}\text { - Income stability and growth } \\
\text { - Decent and healthy life } \\
\text { - Availability of nutritious food }\end{array}$ & $\begin{array}{l}\text { No Poverty, Zero } \\
\text { Hunger, Decent Work \& } \\
\text { Economic Growth, } \\
\text { Reduced Inequalities, } \\
\text { Responsible } \\
\text { Consumption \& } \\
\text { Production }\end{array}$ & $\begin{array}{l}\text { Total Indicators: } 8 \\
\text { Ex: } 1 . \text { Number of small } \\
\text { farmers networked with } \\
\text { supply chain through } \\
\text { investee } \\
\text { 2. \% of produce by } \\
\text { weight and value } \\
\text { lost/damaged in cold } \\
\text { chain }\end{array}$ \\
\hline
\end{tabular}

Table 2: Impact value chain and indicators for education sector

\begin{tabular}{|c|c|c|c|c|c|}
\hline \multirow[t]{2}{*}{$\begin{array}{l}\text { General } \\
\text { Category }\end{array}$} & \multicolumn{3}{|c|}{$\begin{array}{c}\text { Impact Value Chain } \\
\text { (Category- outcome \& impact) }\end{array}$} & \multirow[t]{2}{*}{ Impact Theme } & \multirow[t]{2}{*}{$\begin{array}{l}\text { Indicators } \\
\text { (Codes) }\end{array}$} \\
\hline & Output & Outcome & Impact & & \\
\hline $\begin{array}{l}\text { Primary and } \\
\text { secondary } \\
\text { education }\end{array}$ & $\begin{array}{l}\text { - Primary and } \\
\text { secondary Schools }\end{array}$ & $\begin{array}{l}\text { - Increased literacy } \\
\text { - Affordable and quality } \\
\text { education for all } \\
\text { - With better quality, increased } \\
\text { probability of good higher } \\
\text { education } \\
\text { - Empowering girls through } \\
\text { education } \\
\text { - Increased chances of being } \\
\text { engaged in productive } \\
\text { employment and work }\end{array}$ & $\begin{array}{l}\text { - Evolved human being } \\
\text { - Increased learning opportunities } \\
\text { - Poverty alleviation } \\
\text { - Enlightened human being } \\
\text { paving way to gender equality } \\
\text { - Greater happiness index } \\
\text { - Developing minds of scientific } \\
\text { enquiry and reasoning }\end{array}$ & $\begin{array}{l}\text { No Poverty, Good health } \\
\text { and well-being, quality } \\
\text { Education, Gender } \\
\text { Equality, Decent Work } \\
\text { \& Economic Growth, } \\
\text { Industry, Innovation and } \\
\text { Infrastructure, Reduced } \\
\text { Inequalities }\end{array}$ & $\begin{array}{l}\text { Total Indicator: } 21 \\
\text { Ex: } 1 \text {. Average fees per } \\
\text { student of primary and } \\
\text { secondary } \\
\text { 2. Proportion of children } \\
\text { aged } 5-17 \text { years in } \\
\text { catered area engaged in } \\
\text { child labour by sex and } \\
\text { age }\end{array}$ \\
\hline
\end{tabular}




\begin{tabular}{|c|c|c|c|c|c|}
\hline $\begin{array}{l}\text { Higher } \\
\text { education and } \\
\text { vocational } \\
\text { training, } \\
\text { Parallel and } \\
\text { ancillary } \\
\text { education }\end{array}$ & $\begin{array}{l}\text { - Skill training, } \\
\text { undergraduate/gradua } \\
\text { te/post graduate } \\
\text { degree } \\
\text { - Content development, } \\
\text { tutoring, coaching for } \\
\text { admission test, } \\
\text { teachers training, } \\
\text { technology } \\
\text { development for } \\
\text { disseminating } \\
\text { education, } \\
\text { Assessment test }\end{array}$ & $\begin{array}{l}\text { - Employable youth } \\
\text { - Innovation and knowledge } \\
\text { development } \\
\text { - Affordable, accessible and } \\
\text { quality education for all } \\
\text { - Content development in local } \\
\text { language create learning } \\
\text { opportunity for illiterate as } \\
\text { well } \\
\text { - No discrimination for age and } \\
\text { sex in case of online learning } \\
\text { and have deeper delivery } \\
\text { outreach }\end{array}$ & $\begin{array}{l}\text { - Poverty alleviation } \\
\text { - Healthy and decent life } \\
\text { - Increased GDP } \\
\text { - Innovation and industrialization } \\
\text { - Sustainable production }\end{array}$ & $\begin{array}{l}\text { Impact Theme: No } \\
\text { Poverty, Good health and } \\
\text { well-being, quality } \\
\text { Education, Gender } \\
\text { Equality, Decent Work } \\
\& \text { Economic Growth, } \\
\text { Industry, Innovation and } \\
\text { Infrastructure, } \\
\text { Sustainable production } \\
\text { and consumption, } \\
\text { Reduced Inequalities }\end{array}$ & $\begin{array}{l}\text { Total Indicators: } 15 \\
\text { Ex: } 1 \text {. No. of } \\
\text { unemployed disabled } \\
\text { youth in age category } 21 \text { - } \\
35 \text { having secondary } \\
\text { education } \\
\text { 2. Proportion of youth } \\
\text { living below } 5 \% \text { median } \\
\text { income by sex in age } \\
\text { category } 21-35 \\
3 . \text { No of deaths due to } \\
\text { malnutrition/alcohol/drug } \\
\text { consumption/suicide etc. }\end{array}$ \\
\hline
\end{tabular}

Table 3: Impact value chain and indicators for healthcare sector

\begin{tabular}{|c|c|c|c|c|c|}
\hline \multirow[t]{2}{*}{$\begin{array}{l}\text { General } \\
\text { Category }\end{array}$} & \multicolumn{3}{|c|}{$\begin{array}{c}\text { Impact Value Chain } \\
\text { (Category- outcome \& impact) }\end{array}$} & \multirow[t]{2}{*}{ Impact Theme } & \multirow[t]{2}{*}{$\begin{array}{l}\text { Indicators } \\
\text { (Codes) }\end{array}$} \\
\hline & Output & Outcome & Impact & & \\
\hline $\begin{array}{l}\text { Primary } \\
\text { healthcare, } \\
\text { diagnostic }\end{array}$ & $\begin{array}{l}\text { - Clinics and hospitals } \\
\text { - Diagnostic centre, } \\
\text { devices } \\
\text { - Medical devices } \\
\text { - Medical Research and } \\
\text { Development }\end{array}$ & $\begin{array}{l}\text { - Affordable and accessible } \\
\text { healthcare } \\
\text { - Disease prevention } \\
\text { - Early detection and diagnosis } \\
\text { - Preventable death }\end{array}$ & $\begin{array}{l}\text { - Improved quality of life } \\
\text { - Increased life expectancy } \\
\text { - Health literacy }\end{array}$ & $\begin{array}{l}\text { Zero Hunger, Good } \\
\text { health and well-being, }\end{array}$ & $\begin{array}{l}\text { Total Indicator: } 15 \\
\text { Ex: } 1 . \text { No. of patients } \\
\text { screened for medical } \\
\text { conditions or risk factor } \\
\text { (year wise data) } \\
\text { 2. No of lives saved due } \\
\text { to early detection of } \\
\text { deathly disease like } \\
\text { cancer/ HIV/TB/cardio } \\
\text { etc. }\end{array}$ \\
\hline
\end{tabular}

Source: Outcome and impact are based on SDGs targets, some indicators are selected from IRIS+ and International Indicator Framework 


\section{Analysis and Discussion}

The forthcoming section presents results of study based on survey and impact/financial reports of impact investors and their investees. The section has been divided into two parts. First part interprets the results of survey while second part deals with content analysis of secondary data on developed impact value chain and indicator to set linkages between impact investing and SDGs.

\subsection{Survey Results}

Survey shows the demographic presence of impact investors is concentrated in Maharashtra, Karnataka, New Delhi and Tamilnadu. However, investee spread is much wider; also every investor identified itself as impact investor. Impact investors believe in providing seed funding (mostly) and Series-A funding investment but vehicle used for investing is variable with $78 \%$ equity, $15 \%$ debt and 7\% debt and equity both. Total Asset under Management (AUM) varied between $\$ 0.15 \mathrm{mn}$ to $\$ 88.97 \mathrm{mn}$ averaging at $\$ 36 \mathrm{mn}$ (Source: IIC data). Priority sector for investment is still Financial Inclusion but Education \& Training, Healthcare and agriculture are also not lagging far behind. High dependence on agriculture of bottom billion and role of education and training in uplifting their status may attract a significant impact investment in future in these sectors. Government of India initiative in WASH and energy will also mobilize impact investment in these sectors. No of investee across sectors are shown in Figure 1.

Figure 1: No of investees operating in different sectors

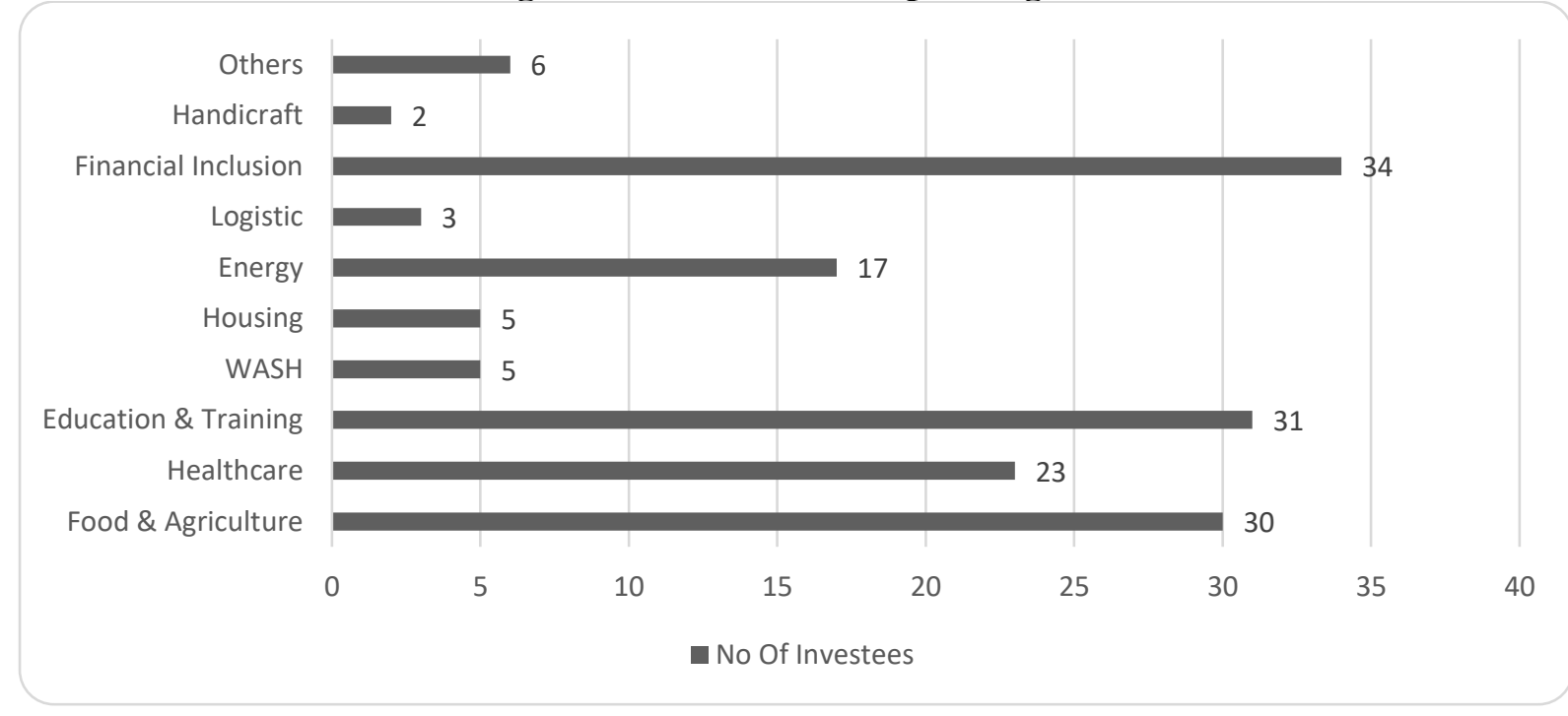

Source: Compiled by Authors on the basis of questionnaire' responses.

Question of selection criteria of investee received varied response while $70 \%$ have pre-identified sectors to select investees, $30 \%$ goes with the alignment of objectives. When asked about preselected standard metrics for impact measurement in chosen sector, 60\% decline, while $40 \%$ developed some from experience with other and drawing knowledge from international community. Survey found that $80 \%$ measure impact but only $20 \%$ use international standard 
metric like IRIS, PRISM ${ }^{15}$ etc as reference, remaining $60 \%$ use self-developed metrics, rest $20 \%$ use international standard metrics reason being lack of experience, knowledge and resources at investee level. However, all impact investor believe their investment objectives are aligned with SDG but only $60 \%$ shows inclination to use metrics developed on the basis of SDGs target. The biggest hurdle in impact measurement is availability of data due to shortage of resources and time and knowledge and experience of investee. The challenges of impact industry identified are: -

Figure 2: Challenges faced by Impact Investor

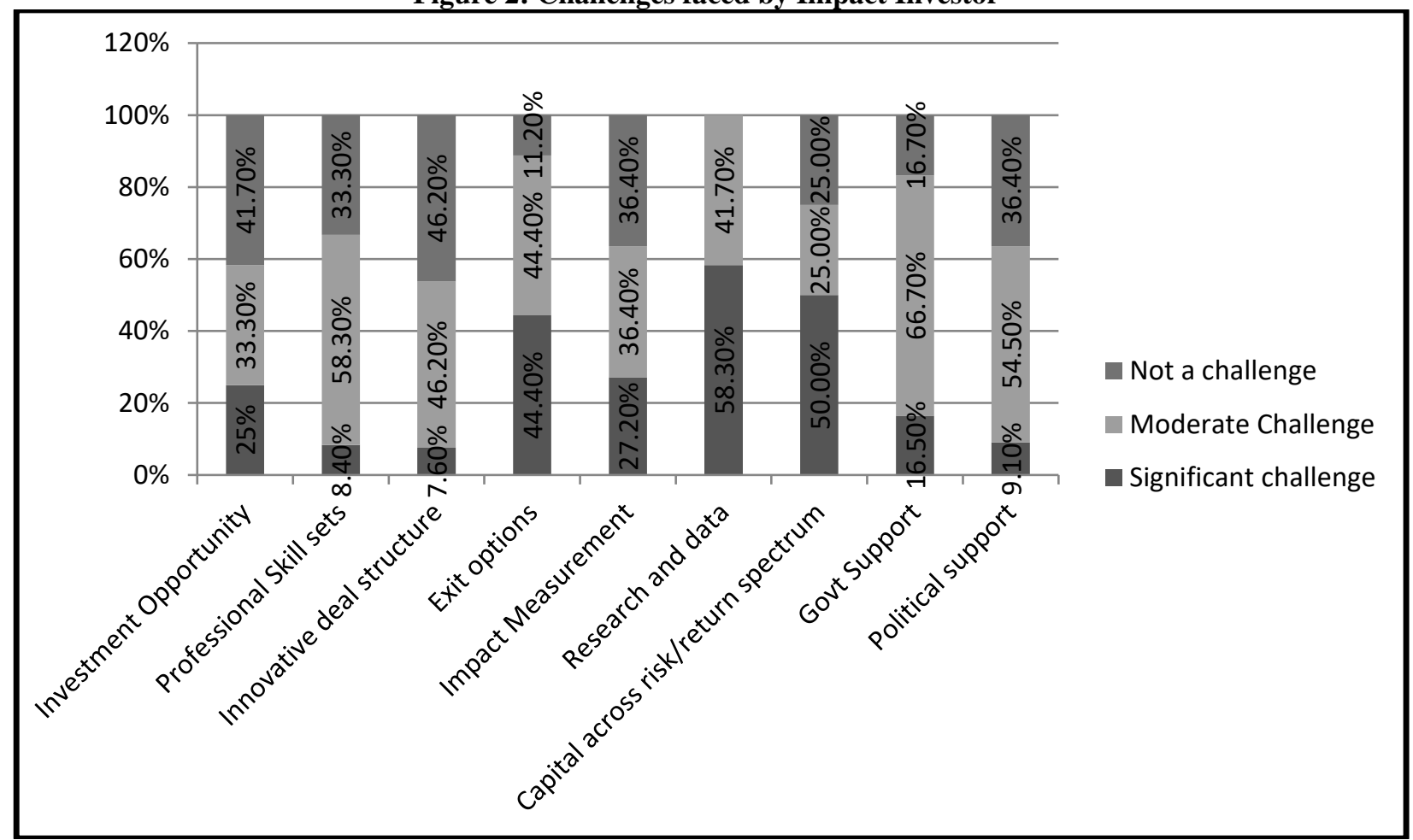

Source: Brookings Survey 2019

As visible research and data, capital across risk and return and exit options are considered as significant challenge by $58.3 \%, 50 \%$ and $44.4 \%$ respectively, government Support, political support and professional skill sets are considered as moderate challenge by $66.7 \%, 54.5 \%$ and $58.3 \%$ respectively.

\subsection{Disclosure Analysis}

To do content analysis, impact reports of investors have been segmented into three segments; each segment contains information related to chosen sector of agriculture, education and healthcare. Since deductive reasoning design is being used, there is pre developed list of codes. Developed/selected indicators have been used as codes and categorised under outcome and impact as per developed impact value chain. To ensure the validity of outcome, one coder acted as a primary coder and another checked the result, if any inconsistency is found, it has been resolved by mutual consultation.

\footnotetext{
${ }^{15}$ PRISM (Portfolio Risk, Impact and Sustainability Measurement) is an impact fund performance assessment platform, it integrates the fund's performance (measured by fund Sustainability, Intent and Contribution score PSIC) with the performance of each portfolio company (measured by Portfolio Impact Assessment Score PSIA)
} 
Impact reports are wider in scope and contain more qualitative information than quantitative, invariably all investor's impact report have spoken about SDGs and how many SDGs they are contributing to, sector wise analysis is as follows:

\section{Agriculture:}

Thirty investees are funded by impact investor in this sector wherein one involved in financial support to smallholder farmer, since indicators have not developed for financial inclusion; one investee has been left from analysis. Thirteen investees operate in technology, information, input support; waste management etc. and sixteen are specifically for smallholder farmer. Since impact reports contain information about all portfolio investments/investees, the outcome and impact (figure 3), investees operating in technology, information and waste management category, tried to achieve are income stability and growth (100\%), increased production (56.48\%), sufficient and sustainable production (56.8\%). Agriculture waste management (15.38\% and affordable produce $(15.38 \%)$ is the least preferred outcome, the result shows a greater work toward SDG - No Poverty, Zero Hunger, Responsible Consumption and Production.

Figure 3: Impact Category- Technology, Information, Waste Management

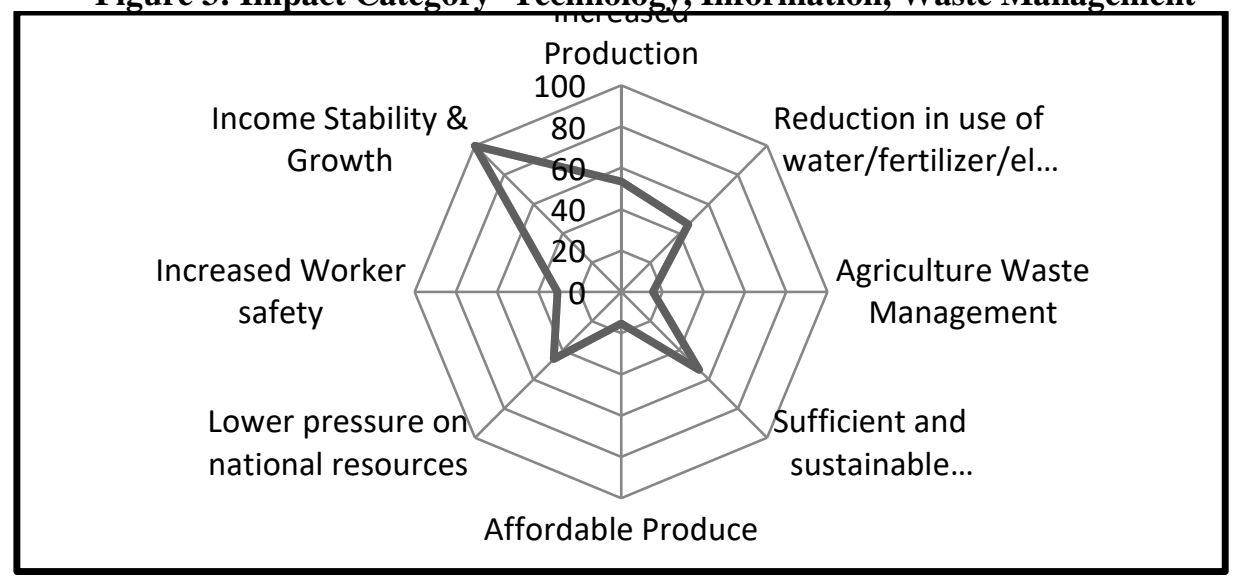

Source: Compiled by Authors on the basis of content analysis of Impact Reports

The outcome and impact (figure 4) achieved by investees operating in main category of Smallholder Farmer are income stability and growth $(81.25 \%)$, decent \& healthy life $(81.25 \%)$, increased opportunity (68.25\%). Quality and nutritious crop $(6.25 \%)$ is the least preferred outcome. 
Figure 4: Impact Category-Smallholder Farmer

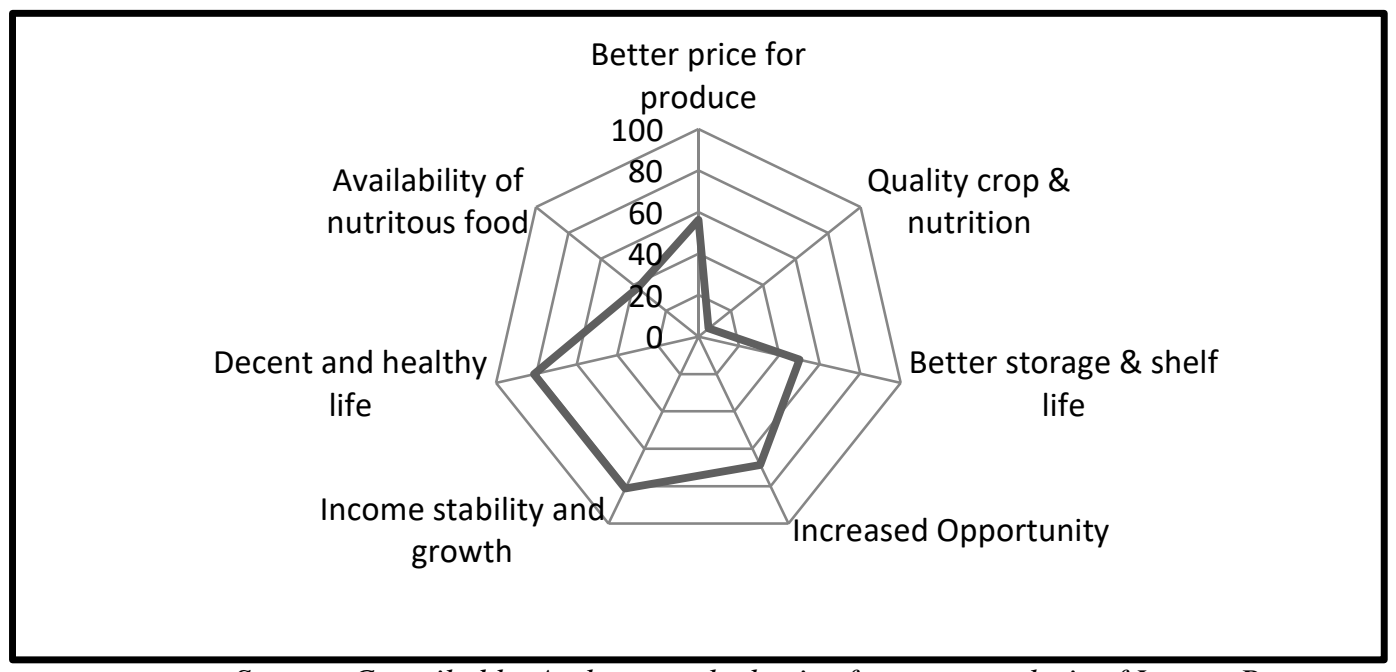

Source: Compiled by Authors on the basis of content analysis of Impact Reports

\section{Education:}

Impact investment in education sector is largely confined in parallel and ancillary education and skill training as K-12 education segment is mostly regulated (Malani, 2016). Thirty investees are funded by impact investor in this sector wherein three involved in financial support; indicators for this impact category were not developed, causing to leave out these three investees. The results of content analysis for this impact category is given in figure 5, category of innovation and knowledge development $(59.25 \%)$, deeper delivery outreach $(55.56 \%)$ and affordable, accessible quality education for all $(51.85 \%)$ have been the preferred one, while learning opportunity for all $(14.81 \%)$ and sustainable production (14.81\%) got fewer mention. Reason being, due to high regulation in K-12 sector, effort to support BoP population has been put in parallel education. With increasing internet connectivity and deeper penetration of mobile connectivity, innovations are happening in online space which creates a broader delivery outreach without any discrimination being done for age, sex and economic status.

Figure 5: Impact Category-Parallel and Ancillary Education

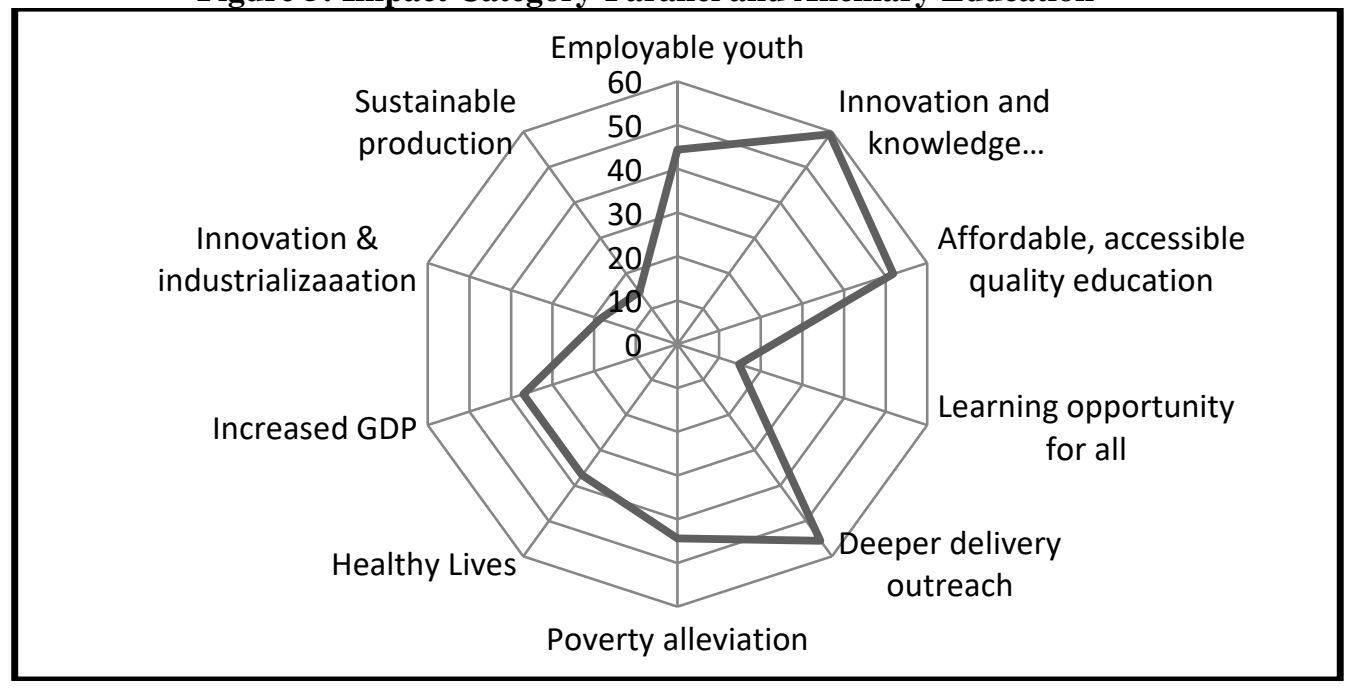

Source: Compiled by Authors on the basis of content analysis of Impact Report 


\section{Healthcare:}

Large poor population live in rural India and affordable and accessible healthcare is in the poorest state in this area, making impact investors funding enterprises who are creating inroads in rural healthcare. Impact investors have funded twenty-three investees operating in healthcare sector; two were in financial support hence left out from analysis. Improved quality of life (76.19\%), affordable and accessible healthcare (57.14\%), early detection and diagnosis $(57.14 \%)$ are the most sought after outcome/impact by investees operating in this sector. Increased life expectancy $(4.76 \%)$ is the least mentioned category in reports; the probable reason could be it is a long term impact. The most contributed SDG in this sector is Good health and Well Being.

Figure 6: Impact Category: Primary Healthcare and Diagnostic

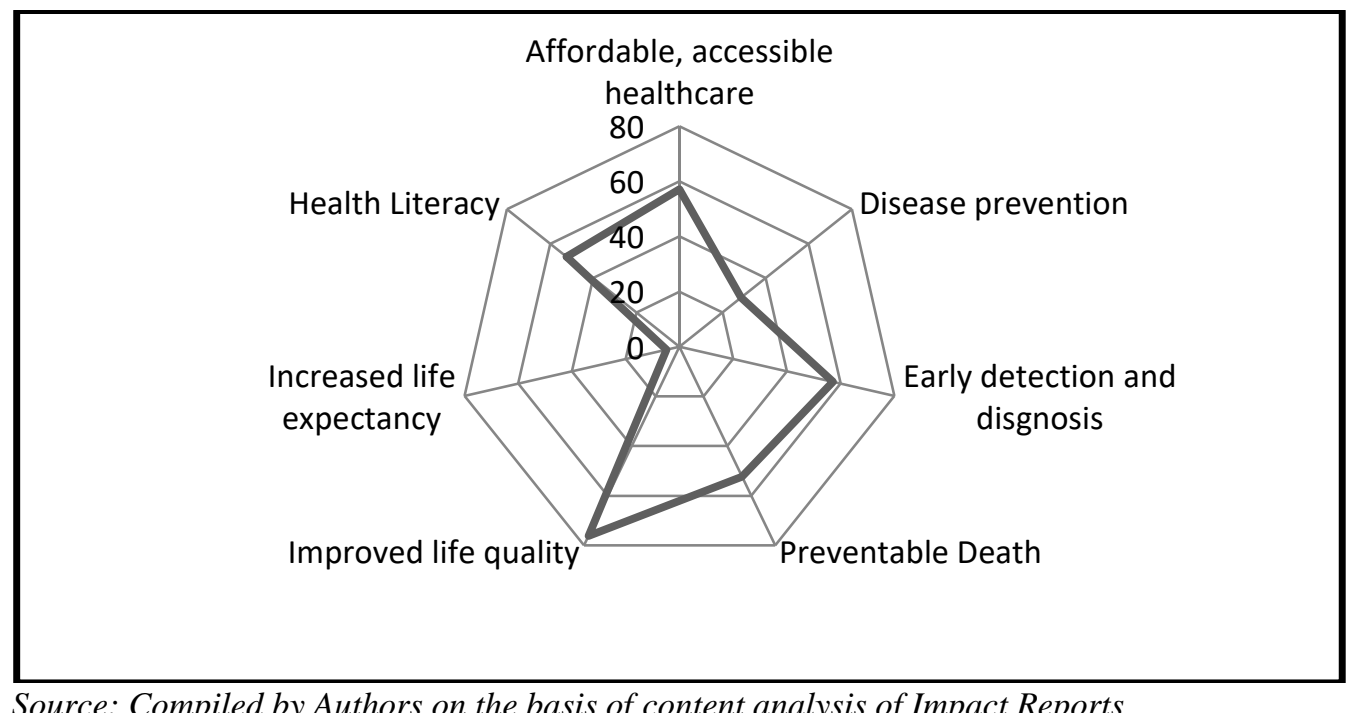

The study has been conducted to develop an understanding of impact investing market in India and establish a positive link between impact investment and SDGs. We have observed that impact investing is making every effort to drive itself in the direction of achieving sustainable development and investing in organisation working closely with BoP (base of pyramid) population. A similar study by Brooking and McKinsey in 2019 and 2017 respectively also established that impact investing has found its place in India and doing public good with private money.

Impact measurement is still a grey area and requires measurable, cost effective and credible indicators having global acceptance. SDGs targets provided the opportunity for impact investing to measure and manage impact based on these targets. Impact investing has imbibed the SDGs as evident from content analysis but measurement of the scale of its contribution is difficult in absence of quantified financial data.

\section{Conclusion}

The argument of McCreless (2017) "in the absence of data, all we have our deeply held personal conviction, the only way to know would be if you had data on impact and data on financial return, and you put them together. To be sure, there have been several reports on financial return of various segments of impact investing, but these reports don't have any actual impact data" highlights the absence of quantifiable yardsticks to measure the impact and assimilation of this impact with the 
financial return. Impact is sometimes so loosely defined (Shamika et al., 2019) that it widens the horizon to such a limit where even perspective of measuring it is not feasible; on the other hand, sometimes it is narrowed to only activities and output of investees and hence fails to capture the real impact in the lives of other stakeholders, both the views are detrimental to the concept of impact measurement. To measure impact in meaningful way we require a pristine understanding of causal links, what our activities are and what are their output and how this linkage created the desired outcome and we are able to observe and tabulate when the aggregation of outcome over the period created an impact. "Context oriented metrics are developed to design traceable indicators to quantify external context and impact of investment" (Vorosmarty et al., 2018). In the present study we tried to create link between SDGs and indicators based on visualised outcome and impact. Since indicators are established on the basis of SDGs targets and International Indicator Framework of SDGs, their presence in impact report indicates connectivity between impact and SDGs and demonstrates that impact created by investors and investees is positively linked with SDGs. How can be answered from this study but to answer how much, quantitative data is required on established indicators along with baseline data. Baseline data for the region and markets can be created when national data is broken into smaller units. But so far we can clearly assume impact investing is a vehicle to fund sustainable development, also it is private investing that can create public good.

\section{Managerial and Societal Implications}

We all surely want to 'sign up' to reach sustainable development goals in the hope that by 2050 there will be narrower gap between the lifestyle that privileged societies enjoy and which is available to rest of the world (Rees, 2018), impact investors are trying to bridge this gap between have and have-not. How far their efforts achieved this objective will not be deciphered until we have quantified and measurable indicators, since established indicators are aligned with SDGs targets and indicators, it gives them a credible basis (Schonewille, 2018) and present study proves the possibility of applying the established indicators for impact measurement by investors in quantifiable terms.

\section{References}

Addy, C., Chorengel, M., Collins, M. \& Michael, E. (2019). Calculating the value of impact investing. Harvard Business Review, February 2019. Available at doi:https://hbr.org/2019/01/calculating-the-value-of-impact-investing

Berelson, B. (1952). Content analysis in communication research. Free Press.

Berg, B.L. (2001). Qualitative research method for social sciences. Allyn and Bacon. ISBN 0205-31847-9

Brest, P. \& Born, K. (2013). When can impact investing create a real impact?. Stanford Social Innovation Review, 11(4), 22-31, Available at doi:https://ssir.org/articles/entry/impact_investing 
Brimble, M., Vyvyan, V., and Ng, C. (2013). Belief and Investing: Preferences and Attitudes of the Faithful. Australasian Accounting, Business and Finance Journal, 7(1), 23-41. doi:10.14453/aabfj.v7i1.3

Chua, C., Gupta A., Hse, V., Jimenez, J. \& Li, Y. (2011). Beyond the margins: Redirecting Asia's capitalism. Advantage Ventures, Hong Kong. thegiin.org/research/publication/beyondthe-margin-redirecting-asias-capitalism

Davis, K.E., Fisher, A., Kingsbury, B., \& Marry, S.E. (2012). Governance by Indicators: Global Power through Quantification and Rankings. Oxford University Press.

doi: https://doi: 10.1093/acprof:oso/9780199658244.001.0001

De Silva Lokuwaduge, C.S., Smark, C., and Mir, M. (2020). Sustainable Development Goals and Businesses as Active Change Agents. Australasian Accounting, Business and Finance Journal, 14(3), 1-5. doi:10.14453/aabfj.v14i3.1

Epstein, M.J., Yuthas, K. (2014). Measuring and improving social impact: A guide for nonprofits, companies and impact investors. Barrett-Koehler Publishers. ISBN 978-1-60994-977-8, e-book ISBN 978-1-60994-978-5

IRIS and Global Impact Investing Network (2019). https://iris.thegiin.org/metrics

Hehenberger, L., Harling, A., Scholten, P. (2013). Practical guide to measuring and managing impact. European Venture Philanthropy Association, Brussels, Belgium. https://evpa.eu.com/knowledge-centre/publications/measuring-and-managing-impact-apractical-guide, ISBN 9789082316087

Jackson, E.T. (2013). Interrogating the theory of change: evaluating impact investing where it matters most. Journal of Sustainable Finance \& Investments, 3(2), 95-110. doi: https://doi: 10.1080/20430795.2013.776257.

Krippendorff, K. (2004). Content analysis: an introduction to its methodology. Sage Publications. ISBN: 9781506395661

Le Blanc, D., (2015). Towards integration at last? The sustainable development goals as a network of targets. Sustainable Development, 23, 176-187. doi: https://doi.org/10.1002/sd.1582

Levine, A. \& Emerson, J. (2011). Impact Investing-Transforming how we make money while $\begin{array}{lllll}\text { making a } & \text { difference. }\end{array}$ http://www.mitpressjournals.org/doi/pdf/10.1162/INOV_a_00077

Lewis, E., Pinchot, A., Christianson, G. (2016). Navigating the sustainable investment landscape. World Resources Institute, Washington DC. https:/www.wri.org/research/navigatingsustainable-investment-landscape

Malani, S. (2016). Impact investing in $K-12$ education in India. http://www.villgro.org/2016/05/26/Impact-Investing-in-School-Education-in-India/ 
McCreless, M. (2017). Bono doesn't know-All of us are still learning. Stanford Social Innovation Review. Available

at: https://ssir.org/articles/entry/bono_doesnt_knowand_neither_do_the_rest_of_us.

Neuendorf, K.A. (2002). The content analysis guidebook. Sage Publications. ISBN: 9781412979474

Morgan, J.P. (2010). Impact Investments: An emerging asset class. Rockefeller Foundation \& Global Impact Investing Network. https://core.ac.uk/download/pdf/71352133.pdf

O’Flynn, P. \& Barnett,C. (2012). Evaluation and Impact Investing: A review of methodologies to assess social impact. Institute of Development Studies \& Centre for Development Impact, https://www.researchgate.net/publication/325049649_Evaluation_and_Impact_Investing _A_Review_of_Methodologies_to_Assess_Social_Impact

Padel, F., Dandekar, A., Unni, J. (2015). Ecology economy quest for a socially informed connection. Orient Blackswan. ISBN: eISBN 9788125055044.

Reeder, N. \& Colantonio, A. (2013). Measuring impact and non-financial returns in impact investing: A critical overview of concepts and practice. Working paper, London school of Economics \& Political Science and European Investment Bank Institute. https://lsecities.net/wp-content/uploads/2013/10/Measuring_Impact-full-length-Oct2013.pdf

Rees, M. (2018). On the future: prospect for humanity. Princeton University Press. ISBN: 9780691180441

Reisman, J.,Olazabal, V. \& Hoffman, S. (2018). Putting the "Impact" in impact investing: The rising demand for data and evidence of social outcomes. American Journal of Evaluation, 20(10), 1-7. doi: https://doi.org/10.1177/1098214018779141

UN SDG Indicators (2019). https://unstats.un.org/sdgs/indicators/indicators-list/.

Shamika, R., Wright, E.G., Sharma, P. \& Jones, I.B. (2019). The Promise of Impact Investing in India. Brooking India, Research Paper No. 072019. https://www.brookings.edu/research/the-promise-of-impact-investing-in-india/

Schonewille, T. (2018). The use case of sustainable development goals for impact investment measurement (Paper presentation). 2018 12 $2^{\text {th }} @ \mathrm{Q}$ conference proceedings, session VII: money, Queen's University, Charlotte, USA. doi: https://doi.org/10.24908/iqurcp.11648

Vorosmarty, C.J., Osuna, V.R., Koehler, D.A., Klop, P., Spengler, J.D., Buonocore, J.J., Cak, A.D., Tesseler, Z.D., Corsi,F., Green, P.A. \& Sanchez R. (2018). Scientifically assess impact of sustainable investments. Science, 359(6375), 523-525. doi: https://doi.org/10.1126/science.aao3895 
Wendt, K. (2018), Positive impact investing: A sustainable bridge between strategy, innovation, change \& learning. Sustainable Finance Book Series, Springer. doi: https://doi.org/10.1007/978-3-319-10118-7 